\section{Relativization Strategies of Sasak Ngeno Ngene Dialect in Lombok}

I Nurachman Hanafi

2 Udin

3 Eni Djuhaeni

4 Edy Syahrial

1234 Universitas Mataram, Lombok, Indonesia

\begin{abstract}
Relative clauses (RC), in whatever the languages, are essential for investigation especially on how noun phrases as nuclear and oblique relations are workable in Keenan \& Comrie's (1977) Noun Phrase Accessibility Hierarchy. In this paper, Relativization Strategies of Sasak Ngeno-Ngene Dialect in Lombok is presented with the aims are (1) describing the ability of these relations in direct relativization, (2) analyzing the strategies used when indirect relativization occurs, and (3) formulating the right orderings of these relations in the hierarchy. The data on relativization strategies were taken by elicitations, an interview with some informants and documentation of the previous related studies. Then, a careful analysis was made with reference to common linguistic typological approach. The results of this study showed that: (1) gap strategy underlines direct relativization for $S$ (subject) of SVO, 0 (object) of OVS and OBL of destination, (2) case-coding strategy is preferred by $\mathrm{OBL}$ of locative, and (3) passivization strategy is suitable for all indirect relativizations for 0 (object) of SVO and OBL of benefactive, recipient, and instrumental. The hierarchy of nuclear and oblique relations were formulated: $\mathrm{S}(\mathrm{SVO})>0(\mathrm{OVS})>\mathrm{OBL}(\mathrm{DES}>\mathrm{LOC})$ in direct relativization. Conversely, the hierarchy of 0 (SVO) $>0 B L$ (BEN > RECIP > INST) is shown in indirect relativization.
\end{abstract}

\section{Keywords}

relativization

nuclear relations

case-coding strategy

\section{Ethical Lingua}

Vol. 7, No. 1, 2020

ISSN 2355-3448 (Print)

ISSN 2540-9190 (Online)

Corresponding Email

Nurachman Hanafi

hanafinurachman@gmail.com

Article's History

Submitted 8 March 2020

Revised 9 April 2020

Accepted 10 April 2020

DOI

$10.30605 / 25409190.162$

Copyright (๑) 2020

The Author(s)

This article is licensed under CC BY-NC-SA 4.0 License

\section{(cc) BY-NC-SA}




\section{Relativization Strategies of Sasak Ngeno Ngene Dialect in Lombok}

In Linguistic typology, relative clauses (RCs) are essential for investigation on how noun phrases as nuclear and oblique relations are workable in Keenan \& Comrie's (1977) Noun Phrase (NP) Accessibility Hierarchy. Comrie (1992) mentioned two types of relative clauses: restrictive and non-restrictive. The first illustrates the presence of a relative marker right after a noun phrase in a clause as in the boy who walked alone in the rain was my grandson. The second shows a relative marker directly after a comma in the girl, whom I saw in the rain alone, was my neighbor. Here, the markers who for $\mathrm{S}$ (subject) and whom for 0 (object) are performed in two different contexts of situation. Amongst the two RCs, a restrictive clause is more accessible for NP analysis in the hierarchy.

The NP Accessibility Hierarchy $(\mathrm{AH})$ can be described as follows:

$$
\mathrm{SU}>\mathrm{DO}>\mathrm{IO}>\mathrm{OBL}>\mathrm{GEN}>0 \mathrm{COMP}
$$

where > means 'is more accessible than'. SU stands for Subject, DO Direct Object, IO Indirect Object, OBL Oblique, GEN Genetive, and O COM stands for Object of Comparison. Keenan \& Comrie (1977) highlighted the positions of NP at the top of the AH that are universally accessible to relativization. Example [2] demonstrates this.
a. Jack hit Crocodile Dundee
[main clause]
b. Jack who hit Crocodile Dundee
c. Crocodile Dundee whom Jack hit

Example [2a] bears two argument NPs Jack and Crocodile Dundee with respective functions as $S$ (subject) and 0 (object). In [2b], the relative marker who is used to relativize $S$, whereas in [2b], who signals 0 relativization. It is then concluded that English is a perfect language for direct relativization simply because their NPs are accessible to all positions in the AH.

Comrie (1992) argues not all languages behaving like English in relativizing their argument NPs. He saw some obstacles for many of them. Indonesian [3b] which confines 0 in direct relativization is one example. Note that in the next explanation, glosses $\mathrm{S}$ and $\mathrm{O}$ are used to replace SU and DO (see Hanafi 2001; 2019).

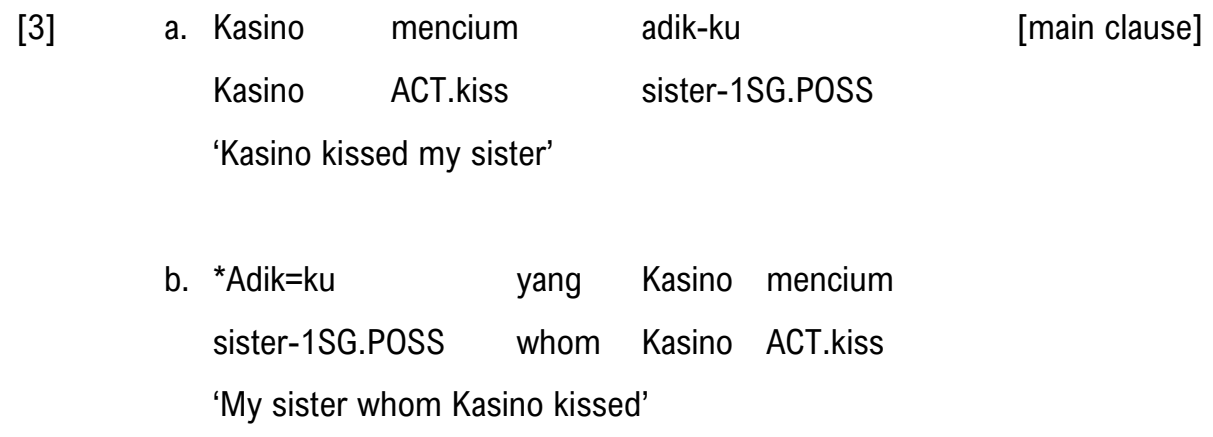

Based on linguistic features, several strategies are employed to fulfill NP relativizations. Givon (1990) introduced a gap strategy for languages having strict word-orders. This strategy takes place in direct relativization. English examples [4b]-[4d] show this: 

a. John killed the dragon in the zoo.
b. John who killed the dragon in the zoo.
c. The dragon that John killed in the zoo.
d. The zoo where John killed the dragon.

[main clause]

Example [4a] is an underlying clause whereas [4b]-[4d] are its derivations. John, the dragon and the zoo whose functions as S, 0 and locative $\mathrm{OBL}$ can be relativized directly simply because the verb killed persists. Here are some relative markers who, that and where engaged in [4].

Pronominal retention strategy is accessible to relativize $S$ possessive but not $S$ in Malay as Comrie (1992) asserts. A similar situation occurs in Indonesian [5]-[6] from Hanafi (2006):

$\begin{array}{lllll}\text { Gadis } & \text { [yang ibu=nya } & \text { membenci saya] } & \text { cantik } & \text { sekali } \\ \text { Girl } & \text { REL mother 3SG. POSS } & \text { ACT.hate1SG } & \text { beautiful } & \text { indeed }\end{array}$

'The girl, whose mother hated me, is beautiful indeed'

$\begin{array}{llll}\text { Satpam [yang komandan=nya } & \text { menipu saya] } & \text { telah tiada } \\ \text { Guard REL commander 3SG.POSS } & \text { deceive } 1 \text { SG } & \text { pass away }\end{array}$

'The guard, whose commander deceived me, passed away'

Chinese Mandarin explicates a nominalization strategy in NP relativization. Li \& Thompson (1989) contended that Mandarin presents nongrean 'farmer' as a head noun functioning as $S$ that undergoes relativization in [7]. On the other hand, the head noun nongrean functioning as 0 is relativized in [8]. In the two clauses, nominalizations in relative clauses take place before the head nouns.

$\begin{array}{lll}\text { [7] Zhong } & \text { shuiguo de } & \text { nongrean } \\ \text { grow } & \text { fruit } & \text { NOM farmer }\end{array}$

'The farmers who grow the fruits'

[8] Tameng zhong de shuiguo

they grow NOM fruit

'The fruit that they grow'

Research on the relativization strategies within Keenan \& Comrie's (1977) AH has received wide attention all over the world. Hanafi (2001), Lutfa (2003), Hanafi \& Mahawan (2006) and Shibatani (2008) are a few of them whose interests are on it.

Hanafi (2001) who worked on relativization strategies to nuclear relations ( $S=$ subject and 0 $=$ object) of six languages in Indonesia found that $S$ is accessible for direct relativization with gap strategy. Conversely, the passivization strategy is the only choice for 0 in indirect relativization. Lutfa (2003) who investigated NPs in Ngeno-Ngene RCs, clarified that S of SVO and $\mathrm{O}$ of OVS are more accessible to direct relativization compared to OBL relations. Unfortunately, she did not discuss the orderings of NPs in the AH which are considered important. Hanafi \& Mahawan (2006) examined the employed strategies in direct relativization across languages. They turned up with six common strategies used by those languages. However, they did not include Sasak Ngeno-Ngene dialect as one of their examples. 
Critics over Keenan \& Comrie's RC theory on the AH was delivered by Shibatani (2008). He rejected the claim that $S$ is more accessible than other nuclear relations by giving some evidence on Sasak and Sumbawa RCs whose Topic in these languages is more accessible to relativization than $\mathrm{S}$, like in some other Austronesian languages.

This paper reports on Relativization Strategies of Sasak Ngeno-Ngene Dialect in Lombok with the aims as follows: (1) describing the ability of nuclear and OBL relations in direct relativization within the $\mathrm{AH},(2)$ analyzing the strategy patterns when indirect relativization occurs, and (3) reformulating the orderings of these relations in the $\mathrm{AH}$. The reason for choosing Ngeno-Ngene dialect here is that it is the largest in Lombok, supported by approximately 1.153 .773 people in East Lombok, West Nusa Tenggara (NTB BPS.GO.ID 2019). It is outstanding in its role, amongst others, as a medium of teaching Indonesian to young learners and is widely spoken by the majority of Sasak people of different dialects (Ahmadi, 1996). This dialect has two word-orders: SVO and OVS. The latter is syntactically ergative (Artawa, 1994; Hanafi \& Udin, 2016).

\section{Method}

This research is qualitatively descriptive. It describes the phenomena of relativization strategies of Ngeno-Ngene Dialect in East Lombok. The data were collected from elicitations, interviews, and documentation of the previous research. The elicitations were done to get the real data and interviews with some informants were used to cross-check the data. Other data from documentation of the previous related study were taken for secondary data. Finally, a careful analysis was conducted with reference to the common linguistic typological approach. This approach provides guidelines for identifying patterns in the study of any language and allows description for many syntactic, morphological and phonological phenomena as well (Lehmann 1978).

\section{Results}

The results of relativization strategies on nuclear and oblique relations in Sasak Ngeno Ngene Dialect are presented in Table 1. Three types of strategies occur in direct relativization: (a) gap strategy is for S (SVO), 0 (OVS) and OBL of destination, and (b) case-coding strategy is for $\mathrm{OBL}$ of locative. Conversely, indirect relativization involves the use of (a) passivization strategy for $\mathrm{O}$ (SVO), OBL of benefactive, recipient and instrumental.

Table 1.

Relativization Strategies of Sasak Ngeno-Ngene Dialect

\begin{tabular}{lll}
\hline & Nuclear \& Oblique Relations & Types of Strategy \\
\hline No $1 \quad$ Direct Relativization & S (SVO) & Gap \\
& O (OVS) & Gap \\
& OBL: Locative & Case-coding \\
& OBL: Destination & Gap \\
\hline
\end{tabular}




\begin{tabular}{lll}
\hline & Nuclear \& Oblique Relations & Types of Strategy \\
\hline No 2 Indirect Relativization & O (SVO) & Passivization \\
& OBL: Benefactive & Passivization \\
& OBL: Recipient & Passivization \\
& OBL: Instrumental & Passivization \\
\hline
\end{tabular}

Concerning the reformulation orderings of NPs in the hierarchy, we can say that in (1) direct relativization yields: $S$ (SVO) > O (OVS) > OBL: DES > LOC, whereas in (2) indirect relativization generates: 0 (OVS) > OBL: BEN > RECIP > INST. The relativization strategies of Ngeno-Ngene dialect in two types of relativization are reviewed in discussion section.

\section{Discussion}

\section{Direct relativization}

The following are some nuclear and $\mathrm{OBL}$ relations in direct relativization as follows: $\mathrm{S}, \mathrm{O}, \mathrm{OBL}$ of locative and destination.

\section{$S$ relativization (SVO)}

Example [9a] is the main clause whose core argument NPs are $S$ kanak 'kid' and 0 panaq 'arrow' joined by the main verb singgaq 'borrow'. This verb is morphologically unmarked. In $S$ direct relativization [9b], a relative marker siq and a gap strategy are used to signal it. On the other hand, the direct relativization of 0 , which has been previously promoted to the initial position as a grammatical $S$ in the clause, cannot undergo relativization. This is exhibited in [9c] with an asterisk $\left(^{*}\right)$.

[9]

$$
\begin{array}{lllll}
\text { a. Kanaq } & \text { singgaq } & \text { panaq } & \text { no } & \text { [main clause] } \\
\text { kid } & \text { borrow } & \text { arrow } & \text { DEF }
\end{array}
$$

'The kid borrowed the arrow

b. Kanaq siq singgaq panaq no

kid REL borrow arrow DEF

'The kid who borrowed the arrow'

C. *Panaq siq singgaq kanak no

arrow REL borrow kid DEF

'The arrow that the kid borrowed'

\section{$O$ relativization (OVS)}

In SVO languages, $S$ is more accessible than other core relations in the hierarchy as in [9b]. In OVS languages, however, 0 is more accessible than others. Consider example [10] from Lutfa (2003: 30). 
$\begin{array}{lll}\text { a. Dende Dewi Ratnasari } & \text { iring } & \text { Pepatih } \\ \text { DDR } & \text { guard } & \text { Pepatih }\end{array}$

'Pepatih guarded DDR'

b. Dende Dewi Ratnasari siq iring Pepatih

DDR REL guard Pepatih

'Pepatih who guarded DDR'

c. *Pepatih siq iring Dende Dewi Ratnasari

'Pepatih who guarded DDR'

Clause [10a] shows S Pepatih and O DDR respectively as post and preverbal argument NPs. In this context, the main verb iring 'guard' is unmarked (basic). The process of relativizing 0 in [10b] is morphologically marked with siq and the gap strategy allows such a direct relativization. Conversely, [10c] is ill-formed for S relativization.

\section{Locative relativization (SVO)}

Example [11a] is the main clause of one-place verb construction. It presents the sole argument NP ite 'we' and Gedung Abubakar as locative OBL preceded by a preposition leq right after the intransitive verb merariq 'marry'. Example [11b] displays the promotion of locative $O B L$ to grammatical $S$ in the clause. The locative $O B L-S$ promotion results in the change form of initial $S$ ite into a pronominal clitic $=n e$ and the deletion of leq in the clause. This enclitic $=n e$ assigns with the locative marker taoq. In [11c], the case-coding strategy is taken for the direct relativization of initial locative OBL. This process is registered by the presence of siq.
a. Ite merariq leq Gedung Abubakar [main clause]
3PL marry PREP Gedung Abubakar

'We got married in Gedung Abubakar'

$\begin{array}{lll}\text { b. Gedung Abubakar } & \text { taoq }=\text { ne } & \text { merariq } \\ \text { Gedung Abubakar } & \text { LOC }=3 \mathrm{PL} & \text { marry }\end{array}$

'Gedung Abubakar, the place we got married.'

$\begin{array}{llll}\text { c. Gedung Abubakar } & \text { siq } & \text { taoq }=\text { ne } & \text { merariq } \\ \text { Gedung Abubakar } & \text { REL } & \text { place }=3 P L & \text { marry }\end{array}$

'Gedung Abubakar, the place where we got married'

\section{Relativization of destination}

Clause [12a] consists of $S$ and $O B L$ indicating destination. The $S A k u$ is preverbal while $O B L$ of destination Sintung with a definite marker ino is preceded by a preposition aning 'to' and adverbial rubin yesterday'. The verb lalo 'go' is morphologically unmarked. When OBL of destination undergoes raising to the initial position in the clause, the initial $S$ turns to become a post-clitic $=k u$ which attaches to the preposition aning and followed by an adverbial rubin 
[12b]. The process of direct relativization is realized by the gap strategy and the presence of siq. Example [12c] exhibits this.

$$
\begin{array}{lllllll}
\text { a. Aku } & \text { lalo } & \text { aning } & \text { Sintung } & \text { ino } & \text { rubin } & \text { [main clause] } \\
\text { 1SG } & \text { go } & \text { PREP } & \text { Sintung } & \text { DEF } & \text { yesterday } &
\end{array}
$$

'I went to the Sintung yesterday'

$$
\begin{aligned}
& \text { b. Sintung ino aning }=k u \text { lalo rubin } \\
& \text { Sintung DEF PREP=1SG go yesterday }
\end{aligned}
$$

The Sintung, I went to yesterday'

$$
\begin{aligned}
& \text { c. Sintung ino siq aning=ku lalo rubin } \\
& \text { sintung DEF REL PREP=1SG go yesterday }
\end{aligned}
$$

'The Sintung where I went to yesterday'

\section{Indirect relativization}

Some nuclear and OBL relations of SVO presented in this relativization. They are O, OBL of benefactive, recipient and instrumental.

\section{$O$ relativization (SVO)}

The main clause in [13a] is two place-verb construction. It carries the preverbal NP Jukias S and the postverbal NP acong 'dog' as 0 , and the verb mantoq 'hit' is nasal. In the process of 0 relativization, it has to be firstly promoted to grammatical $S$ in the passive clause and the initial $S$ demotes to pronominal clitic $=n e(3 S G)$ on the verb. This enclitic $=n e$ co-occurs with Juki. In this revaluation, the passive verb is marked with te-prefix and isiq Juki behaves like an agentive adjunct [13b]. In the second process, the initial 0 , which is now taking the position of grammatical $S$ in the passive, undergoes relativization signaled by siq 'that'. In short, [13] takes the passivization strategy for 0 relativization.

[13]

$$
\begin{array}{llll}
\text { a. Juki mantoq acong [main clause] } \\
\text { Juki } & \text { ACT.hit } & \text { dog }
\end{array}
$$

'Juki hit a dog'

b. Acong te-pantoq=ne (isiq Juki)

$$
\text { dog PASS-hit=3SG (by Juki) }
$$

'The dog was hit by Juki'
c. Acong
siq
te-pantoq=ne (isiq Juki)
$\operatorname{dog}$
REL PASS-hit=3SG
(by Juki)

'The dog that was hit by Juki' 


\section{Benefactive relativization (SVO)}

A quasi-applicative is used to explicate the process of benefactive relativization. Accordingly, the quasi-applicative occurs when the underlying transitive clause whose oblique relation is absent as in [14a] Inaq miyaq jaje. When [14a] undergoes applicativeness in [14b], the verb miyaq 'make' receives $=$ ang suffix (gloss APPL) as an applicative marker to denote "a process of valency mechanism to add an argument of a verb" (Spencer 1995). The addition of an argument NP is realized by the presence of Loq Bahrum as an 0 before jaje 'cake' in the clause. So [14b] is a form of a quasi - applicative proposed by Dixon (2012).

Benefactive OBL relativization takes place in two ways. First, Loq Bahrum is promoted to grammatical S position in the passive and the initial S Inaq becomes an agentive adjunct [14c]. The passivization process such as this is signaled by $t e=$ prefix (gloss PASS) on the verb and followed by isiq phrase. Second, benefactive OBL may undergo relativization in [14d] in which siq as a relative marker precedes the passive verb tepiyaqang. In this context, the benefactive OBL takes a passivization strategy for indirect relativization. Consider example [14] below.

[14]
a. Inaq miyaq jaje [main clause] mother ACT.make cake
'My mother made (some) cakes'
b. Inaq miyaq-ang Loq Bahrum jaje
mother ACT.make-APPL Loq Bahrum cake
'My mother made Loq Bahrum (some) cakes'

$\begin{array}{lllll}\text { c. Loq Bahrum } & \text { te-piyaq-ang } & \text { (isiq) } & \text { inaq } & \text { jaje } \\ \text { Loq Bahrum } & \text { PASS-make-APPL } & \text { by } & \text { mother cake }\end{array}$

'Loq Bahrum my mother made some cakes for'

\begin{tabular}{|c|c|c|c|c|}
\hline d. Loq Bahrum & siq & te-piyaq-ang & (isiq) & inaq \\
\hline Loq Bahrum & REL & PASS-make-APPL & by & mother \\
\hline
\end{tabular}

\section{Recipient relativization (SVO)}

Identical with the benefactive OBL relativization above, example [15a] is the basic construction with two argument NPs Allah and kesehatan respectively as $S$ and 0 . When [15a] undergoes applicative process as in [15b], there exists ite 'we' before kesehatan 'health'. Although, the verb ngican is morphologically unmarked APPL, yet [15b] is a form of quasi - applicative as Dixon (2012) suggests.

Recipient $\mathrm{OBL}$ relativization occurs in two ways. First, Ite [15b] should be promoted to grammatical $S$ in the passive which results in the demotion of the initial $S$ to isiq phrase (agentive adjunct) and the verb ngican 'grant' is signaled with te- prefix as a passive marker (gloss PASS) morphologically unmarked and the deletion of timpaq occurs in [15b]. Second, recipient $\mathrm{OBL}$ may undergo relativization in $[15 \mathrm{~d}]$ whose relative marker siq precedes the 
passive verb te-ican. In short, the recipient $\mathrm{OBL}$ retains a passivization strategy in its indirect relativization. Consider example [15] below.

$\begin{array}{llll}\text { a. Allah ngican } & \text { kesehatan } \quad \text { [main clause] } \\ \text { Allah ACT.grant health } & \end{array}$

'Allah granted health'

b. Allah ngican ite kesehatan

Allah ACT.grant.APPL $3 P L$ health

'Allah granted us with health'

c. Ite te-ican kesehatan isiq Allah

3PL PASS-grant.APPL health by Allah

'We were granted by Allah with health'

d. Ite siq te-ican kesehatan isiq Allah

3SG REL PASS-grant.APP health by Allah

'It is us that Allah granted with health'

\section{Instrumental relativization (SVO)}

Clause [16a] is the underlying three-place verb construction of [16b]. In [16a], the S maling 'thief' is marked with sino as a definite marker (gloss DEF) and the 0 balen=k is post-verbally attached by enclitic $=k$ (gloss 1SG.POSS) and then followed by a PP ngadu batu 'with stones' as an instrumental OBL. In [16b], there is a promotion of instrumental OBL to the beginning of the clause results in the demotion of the initial $S$ maling into 0 position which is indexed by suffix =ang as a passive marker on the verb ampes 'throw'. The original 0 balen=k also demotes to an OBL position denoted by a preposition tipaq 'to'. [16c] illustrates a relative marker siq in the process of relativizing the instrumental $\mathrm{OBL}$ and the passivization strategy is adopted for indirect relativization.

$$
\begin{aligned}
& \text { a. Maling sino ngampes balen=k ngadu batu [main clause] } \\
& \text { Thief DEF ACT.throw house=1SG.POSS with stone }
\end{aligned}
$$

'The thief threw my house with some stones'

$\begin{array}{llllll}\text { b. Batu ampes-ang maling } & \text { sino tipaq balen=k } \\ \text { stone throw-PASS thief } & \text { DEF to } & \text { house=1SG.POSS }\end{array}$

'Some stones were thrown by the thief to my house'
c. Batu siq ampes-ang maling sino tipaq balen=k
stone REL throw-PASS thief DEF to house=1SG.POSS

'Some stones that were used by the thief to throw my house' 


\section{Conclusion}

In conclusion, two types of relativizations in RCs of Sasak Ngeno-Ngeno Dialect were found. They are interrelated with the strategies used in relativization. Direct relativization accommodates the use of gap and case-coding strategies triggered by the behaviors of two core argument NPs (S and 0 ), locative OBL and destination OBL. In contrast, indirect relativization allows the application of the passivization strategy because of the obstacles in the direct relativization process. Thus, 0 and $\mathrm{OBL}$ of benefactive, recipient and instrumental belong to this group. It is interesting to note that quasi-applicatives in Ngeno-Ngene Dialect are without underlying clauses for benefactive and recipient OBLs and the applicative verbs are morphologically marked or unmarked APPL. Further research on Sasak quasi-applicatives are encouraged.

\section{Acknowledgment}

This research was funded by DIPA BLU Universitas Mataram, No.1459.A/UN18.L1/PP/2018.

\section{References}

Ahmadi, N. (1986). Kajian Tipologi Sintaksis Bahasa Sasak Dialek Ngeno-Ngene, Unpublished MA thesis, Denpasar: Universitas Udayana.

Artawa, K. (1994). Ergativity in Balinese Syntax. Unpublished Ph.D thesis. Bundoora: La Trobe University.

NTB BPS. (2019). Proyeksi penduduk provinsi NTB 2010-2020. Badan Pusat Statistik Provinsi NTB. Retrieved from https://ntb.bps.go.id at 20 Februari 2020.

Comrie, B. (1992). Language Universal and Linguistic Typology. Oxford: Blackwell Publishers.

Dixon, R. M. W. (2012). Basic Linguistic Theory: Further Grammatical Topic. Oxford: Oxford University Press.

Givon, T. (1990). Syntax: A Functional Typological Introduction. Amsterdam: John Benjamins Publishing Company.

Hanafi, N. (2001). Strategi Relativisasi Argumen Ganda Bahasa Nusantara. Jurnal IImu Pendidikan, 52. pp 840-846.

Hanafi, N. (2019). Syntax. (9 ${ }^{\text {th }}$ edition). Mataram: Mataram University Press.

Hanafi, N. \& Mahawan, S. (2006). Strategi Relativisasi Langsung Secara Lintas Bahasa. Jurnal Lisdaya, 2. pp 1-7.

Hanafi, N. \& Udin, U. (2016). Keterpilahan Intransitif Bahasa Sasak Dialek Ngeno-Ngene. Prosiding Konferensi Masyarakat Linguistik Indonesia. Denpasar: Universitas Udayana.

Keenan, E. L., \& Comrie, B. (1977). Noun Phrase Accessibility Hierarchy and Universal Grammar. Linguistic Inquiry, 8. pp 63-69.

Lehmann, W. P. (ed). (1978) Syntactic typology: studies in the phenomenology of language. Austin: University of Texas Press.

Li, C. \& Thompson, S. A. (1989). Mandarin Chinese: A Functional Reference Grammar. Los Angeles: University of California Press.

Lutfa, C. (2003). A Study on Relativization Strategies of Sasak Ngeno-Ngene Dialect at Jorong Pancor, East Lombok. Mataram: Mataram University.

Shibatani, M. (2008). Relativization in Sasak and Sumbawa, Eastern Indonesia. Language and Linguistics, 9(4). pp 865-916. 
Spencer, A. (1995). Morphological Theory: An Introduction to Word Structure in Generative Grammar. Oxford: Blackwell Publishers, Ltd.

\section{Abbreviations}

$\begin{array}{ll}\text { ACT } & =\text { active marker } \\ \text { AH } & =\text { Accessibility Hierarchy } \\ \text { APPL } & =\text { applicative } \\ \text { BEN } & =\text { benefactive } \\ \text { DEF } & =\text { definite marker } \\ \text { DES } & =\text { destination } \\ \text { DO/O } & =\text { direct object/object } \\ \text { GEN } & =\text { genitive } \\ \text { INST } & =\text { instrumental } \\ \text { LOC } & =\text { locative } \\ \text { NOM } & =\text { nominative } \\ \text { NP } & =\text { noun phrase } \\ \text { OBL } & =\text { oblique } \\ \text { OVS } & =\text { object-verb-subject } \\ \text { PASS } & =\text { passive marker } \\ \text { RC } & =\text { relative clause } \\ \text { RECIP } & =\text { recipient } \\ \text { REL } & =\text { relative marker } \\ \text { SVO } & =\text { subject-verb-object } \\ \text { SU/S } & =\text { subject } \\ 1 S G & =\text { first person singular } \\ \text { 1SG.POSS } & =\text { first person singular possessive } \\ 1 P L & =\text { first person plural } \\ 3 S G & =\text { third person singular } \\ 3 P L & =\text { third person plural }\end{array}$

